\title{
STUDI FENOMENOLOGI TENTANG ALASAN PASIEN DENGAN PENYAKIT HIPERTENSI MASIH TETAP MENJADI PEROKOK AKTIF DI RUMAH SAKIT MUHAMMADIYAH PALEMBANG
}

\author{
Joko Tri Wahyudi, S.Kep.,Ns.,M.Kep ${ }^{1}$, Citra Andera Putri² \\ ${ }^{1}$ Program Studi Ilmu Keperawatan, Institut Ilmu Kesehatan dan Teknologi Muhammadiyah Palembang, \\ ${ }^{2}$ Program Studi Ilmu Keperawatan, Institut Ilmu Kesehatan dan Teknologi Muhammadiyah Palembang, \\ *e-mail: joko.mkep@gmail.com
}

\begin{tabular}{ll} 
& Abstract \\
\cline { 2 - 3 } $\begin{array}{l}\text { Keywords: } \\
\text { Pasien }\end{array}$ Hipertensi, & Hipertensi merupakan penyakit yang umum diderita orang saat ini dan \\
Perokok Aktif & menjadi salah satu penyebab utama kematian dini diseluruh dunia. \\
& Hipertensi disebut juga menjadi salah satu penyakit yang sering disebut \\
& sebagai "pembunuh diam-diam" karena penyakit ini tidak menyebabkan \\
gejala jangka panjang. Faktor yang menjadi pemberat kondisi hipertensi \\
adalah perilaku merokok. Perilaku merokok didefinisikan sebagai \\
aktivitas membakar tembakau yang kemudian dihisap asapnya, baik \\
langsung menggunakan rokok maupun menggunakan pipa. Tujuan: \\
Penelitian ini bertujuan untuk mengeksplorasi apa yang menjadi alasan \\
pasien dengan penyakit hipertensi masih tetap menjadi perokok aktif di \\
Rumah Sakit Muhammadiyah Palembang. Metode: Metode sampling \\
yang digunakan adalah purposive sampling. Metode pengumpulan data \\
yang digunakan adalah wawancara mendalam kepada 5 pasien dan 5 \\
keluarga pasien sebagai triangulasi data. Data diolah dan dianalisis \\
menggunakan tujuh langkah analisa data berdasarkan Colaizzi. Hasil: \\
Berdasarkan hasil yang didapatkan dalam penelitian ini ditemukan 4 \\
tema, yaitu pasien merokok karena merasa sudah sehat, tidak mampu \\
menahan keinginan untuk merokok, keluarga membiarkan dan ingin bisa \\
berhenti merokok. Kesimpulan: \\
didapatkan, dapat ditarik kesimpulan bahwa pasien sebenarnya tau \\
bahaya akan merokok, namun merasa belum mampu dan belum mau \\
untuk berhenti merokok. Diharapkan perawat sebagi pemberi pendidikan \\
kesehatan dapat lebih menyemangati pasien untuk dapat berhenti \\
merokok demi kesehatan pasien.
\end{tabular}

\section{PENDAHULUAN}

Hipertensi merupakan faktor risiko untuk berbagai penyakit kardiovaskular dan stroke (Benjamin dkk, 2017). Hampir semua orang dapat mengalami tekanan darah tinggi. World Health Organization (WHO) menyebut angkanya saat ini terus meningkat secara global. Peningkatan orangorang dewasa di seluruh dunia yang akan mengidap hipertensi diprediksi melonjak hingga 29 persen pada tahun 2025. Di tahun 2020 sekitar 1,56 miliar orang dewasa akan hidup dengan hipertensi. Hipertensi membunuh hampir 8 miliyar orang setiap tahun di dunia dan hampir 1,5 juta orang setiap tahunnya di kawasan Asia Timur-Selatan. Sekitar sepertiga dari orang dewasa di Asia Timur-Selatan menderita hipertensi (World Health Organization, 2015).

Peningkatan kasus hipertensi juga terjadi di Indonesia. Data Riset Kesehatan Dasar (Riskesdas) 
milik Kemenkes RI tahun 2013 menunjukkan bahwa 25,8 persen penduduk Indonesia mengidap hipertensi. Sementara itu, data Survei Indikator Kesehatan Nasional (Sirkesnas) tahun 2016 menunjukkan peningkatan prevalensi hipertensi pada penduduk usia 18 tahun ke atas sebesar 32,4 persen. Lalu data Riset Kesehatan Dasar (Riskesdas) milik Kemenkes RI tahun 2018 menunjukkan bahwa 34,1 persen penduduk Indonesia mengidap hipertensi.

Provinsi Sumatera Selatan khususnya kota Palembang merupakan salah satu wilayah Indonesia yang mempunyai prevalensi hipertensi yang tinggi dibandingkan dengan wilayah-wilayah lain. Berdasarkan data dari Dinkes Provinsi Sumatera Selatan, jumlah penderita hipertensi pada tahun 2007 sebesar 32.902 orang dan pada tahun 2008 berjumlah 32.270 orang. Penyakit hipertensi masuk ke dalam "10 penyakit terbesar januari 2017" di kota Palembang dan menempati peringkat kedua (Dinas Kesehatan, 2017.

Berdasarkan data-data diatas, jumlah penderita hipertensi baik di Dunia maupun di Indonesia masih tinggi. Adapun faktor risiko yang memicu terjadinya hipertensi dibagi menjadi dua yaitu faktor yang tidak dapat dikontrol dan faktor yang dapat dikontrol. Faktor yang tidak dapat dikontrol meliputi usia, jenis kelamin, dan keturunan (genetik). Faktor yang dapat dikontrol meliputi kegemukan (obesitas), dislipidemia (kadar lemak dalam aliran darah tidak normal), stress, konsumsi alkohol berlebih, konsumsi garam berlebih, aktivitas fisik, diet yang tidak seimbang dan merokok (Sudarmoko, 2015).

Merokok merupakan suatu masalah di dalam masyarakat yang dapat menimbulkan banyak kerugian baik dari segi sosial ekonomi maupun kesehatan bahkan kematian (Kemenkes RI, 2011). Berdasarkan data yang didapatkan dari World Health Organization, Indonesia menempati peringkat ketiga dengan jumlah perokok terbesar di dunia setelah negara Cina dan India. Pada tahun 2030 diperkirakan akan mencapai 10 juta jiwa untuk angka kematian perokok di dunia, dan $70 \%$ di antaranya berasal dari negara berkembang, saat ini $50 \%$ angka kematian yang diakibatkan oleh rokok berasal dari negara berkembang (Departemen Kesehatan RI, 2016).
Dari penelitian sebelumnya yang dilakukan oleh Sriani dkk (2016), yang berjudul Hubungan Antara Perilaku Merokok Dan Kebiasaan Olahraga Dengan Kejadian Hipertensi Pada Laki-laki Usia 18 - 44 Tahun Di Wilayah Kerja Puskesmas Sungai Besar Kecamatan Banjarbaru Selatan didapatkan hasil bahwa hipertensi pada orang yang merokok masih tinggi yaitu sebesar 81,35\%.

Dari hasil penelitian oleh indar kurniawan tahun 2017 yang berjudul Hubungan Perilaku Merokok dengan Kejadian Hipertensi di Puskesmas Pajangan Bantul, sebagian responden menderita hipertensi grade 1, dimana hipertensi grade 1 sering terjadi pada laki-laki dengan usia diatas dari 40 tahun lebih cenderung menderita hipertensi. Perilaku merokok dalam penelitian ini dinilai dari frekuensi merokok perhari, jumlah rokok yang dihisap perhari, dan ada tidaknya ketergantungan terhadap tembakau. Jumlah konsumsi rokok perhari dapat digunakan sebagai indicator tingkat merokok seseorang, dalam penelitian ini konsumsi rokok dikategorikan menjadi perokok ringan, perokok sedang dan perokok berat.

Tingginya perilaku merokok pada penderita hipertensi tentu menimbulkan pertanyaan tersendiri bagi orang lain. Karena seperti yang sudah dijelaskan sebelumnya bawah merokok merupakan faktor pencetus dari hipertensi, tentu harusnya saat orang sudah divonis menderita hipertensi akan berhenti merokok. Berdasarkan teori Health Belief Model yang kembangkan oleh Rosenstock et al., tahun 1950-an, ada 5 hal yang mempengaruhi seorang pasien dalam menjaga kesehatan dan memilih pengobatan atas penyakitnya, 2 diantaranya adalah kepercayaan pasien terhadap manfaat suatu metode pengobatan (Perceived Benefits) dan kepercayaan pasien bahwa setiap metode pengobatan memiliki kekurangan dan hambatan (Perceived Barriers) (Burke, 2013). Hal ini tentunya bagi penderita hipertensi sudah mengetahui bahwa merokok akan memperberat hipertensinya dan menjadi hambatan (barriers) bagi kesembuhan, namun penderita hipertensi masih tetap menjalani perilaku merokoknya. Oleh karena itu peneliti berkeinginan mencari alasan mengapa pasien dengan penyakit hipertensi masih tetap merokok. 


\section{METODE PENELITIAN}

Penelitian ini menggunakan desain penelitian kualitatif dengan pendekatan fenomenologi. Panduan wawancara yang digunakan pada penelitian ini adalah jenis panduan wawancara yang semi terstruktur. Wawancara dilakukan pada dua sumber, yaitu kepada partisipan dan keluarga partisipan. Wawancara yang dilakukan kepada partisipan untuk menggali data utama dan wawancara kepada keluarga partisipan untuk memvalidasi data yang diperoleh dari partisipan sebagai proses triangulasi sumber. Seandainya keluarga penunggu partisipan berganti-ganti, maka keluarga yang akan diwawancara adalah yang paling dekat dengan partisipan atau Significant Other (SO) dari partisipan dan yang paling lama menunggu partisipan.

Populasi dalam penelitian ini adalah seluruh penderita hipertensi yang merokok di Rumah Sakit Muhammadiyah Palembang. Partisipan dalam penelitian ini adalah pasien dengan penyakit Hipertensi yang masih merokok di Rumah Sakit Muhammadiyah Palembang. Pasien dengan penyakit hipertensi merupakan partisipan untuk data utama, sementara itu anggota keluarga yang menemani pasien berobat atau yang paling lama bersama pasien dapat dimintai informasi sebagai triangulasi sumber untuk kredibilitas data penelitian. Pada penelitian ini terdapat 5 pasien sebagai partisipan utama dan 5 keluarga pasien sebagai triangulasi data yang didapatkan dari partisipan utama.Pada penelitian ini teknik sampling yang digunakan adalah purposive sampling. Teknik analisis data yang akan dilakukan pada penelitian ini menggunakan langkah-langkah analisa data berdasarkan Colaizzi (Colaizzi 1978, cit Holloway \& Wheeler, 2010). Terdapat 7 langkah dalam analisis data menurut Coallizi yaitu : (1) Menuliskan hasil wawancara mendalam pada sebuah transkrip yang menggambarkan semua kata-kata yang diucapkan partisipan, (2) Mengidentifikasi setiap deskripsi dan frase atau kalimat partisipan yang secara langsung berhubungan dengan fenomena yang diteliti, (3) Menguraikan arti dari setiap pernyataan yang signifikan, hal ini dikenal sebagai proses merumuskan makna, (4) Mengatur keseluruhan makna kemudian merumuskannya ke dalam kelompok sub kategori, kategori, dan tema dengan kalimat peneliti, (5) Tema yang didapatkan dari tiap partisipan yang memiliki kedekatan makna kemudian dikelompokkan, dideskripsikan kedalam narasi, (6) Merumuskan deskripsi lengkap dari fenomena yang diteliti dengan pernyataan yang tegas dalam bentuk narasi agar mudah dipahami, (7) Langkah validasi akhir dilakukan melalui verifikasi data yang diperoleh kepada partisipan melalui wawancara.

\section{HASIL PENELITIAN}

\section{Karakteristik Partisipan}

Berdasarkan hasil penelitian, didapatkan bahwa Partisipan dalam penelitian ini adalah pasien dengan penyakit hipertensi yang masih menjadi perokok aktif di rumah sakit Muhammadiyah Palembang berjumlah 5 orang. Seluruh partisipan telah berusia diatas 40 tahun dengan 5 partisipan dengan jenis kelamin laki-laki. Berdasarkan pendidikan, terdapat 1 partisipan dengan pendidikan Sekolah Dasar (SD), 2 partisipan dengan pendidikan Sekolah Menengah Pertama (SMP), 1 Partisipan dengan pendidikan Sekolah Menengah Atas (SMA) dan 1 partisipan dengan pendidikan Perguruan Tinggi (PT). Pekerjaan partisipan antara lain 3 partisipan sebagai karyawan swasta, 1 partisipan sebagai buruh, 1 partisipan sebagai tani. Riwayat merokok partisipan rata-rata dimulai sejak usia diatas 10 tahun. Tiga dari 5 partisipan dengan diagnosa Penyakit HHD disertai Hipertensi dan 1 partisipan dengan diagnosa Hipertensi. Kemudian untuk partisipan sebagai triangulasi data utama, 3 dari 5 partisipan triangulasi merupakan pasangan hidup partisipan utama (suami atau istri) dan 2 sisanya merupakan anak dari partisipan utama. Seluruh partisipan telah berusia diatas 40 tahun. Karakteristik tabel secara rinci juga ditampilkan pada tabel 1 . 
Tabel 1. Karakteristik Partisipan Penelitian Pengalaman Pasien dengan Penyakit hipertensi dengan riwayat merokok di Rumah Sakit Muhammadiyah Palembang Tahun 2020

\begin{tabular}{cccccccc}
\hline Kode & Inisial & $\begin{array}{c}\text { Jenis } \\
\text { Kelamin }\end{array}$ & $\begin{array}{c}\text { Usia } \\
\text { (Tahun) }\end{array}$ & Pendidikan & Pekerjaan & Diagnosa & $\begin{array}{c}\text { Merokok } \\
\text { Sejak }\end{array}$ \\
\hline P1 & Tn. D & Laki-Laki & 62 & SD & Tani & Hipertensi & 13 Tahun \\
\hline P2 & Tn. K & Laki-Laki & 45 & SMP & Buruh & Hipertensi & 15 Tahun \\
\hline P3 & Tn. M & Laki-Laki & 47 & PT & Karyawan & Hipertensi & 17 Tahun \\
\hline P4 & Tn. T & Laki-Laki & 50 & SMA & Karyawan & Hipertensi & 14 Tahun \\
\hline P5 & Tn. A & Laki-Laki & 53 & SMP & Karyawan & Hipertensi & 14 Tahun \\
\hline Sumber: Data Primer, 2020 & & & & &
\end{tabular}

Sumber : Data Primer, 2020

\section{Tema}

Berdasarkan hasil wawancara mendalam dan analisis data menggunakan langkah-langah diatas, didapatkan 4 tema terkait pengalaman pasien dengan penyakit hipertensi dengan riwayat merokok. Lima tema tersebut antara lain 1) Merasa sudah sehat, 2) Tidak dapat menahan keinginan untuk merokok, 3) Keluarga Membiarkan, 4) Ingin Berhenti Merokok.

\section{Tema 1 : Merasa Sudah Sehat}

Tema ini mendeskripsikan tentang bagaimana kondisi dan keadaan penyakit hipertensi yang diderita oleh partisipan. Berdasarkan hasil wawancara mendalam dengan partisipan mengatakan setelah merokok partisipan tidak merasakan gejala apa-apa. Hal ini dapat dilihat dari hasil wawancara sebagai berikut.

"saya sudah lama merokok sejak saya berumur 17 tahun, sekarang saya menderita hipertensi tapi saya tidak merakan gejala-gejala setelah saya merokok dan saya merasa baik-baik saja" (P3, Laki-laki, 47 tahun). "Ya mas, saya kan pernah berhenti merokok karna saya menderita hipertensi tapi saya merokok kembali setah saya merokok kembali saya tidak merasakan gejala apa-apa lagi sejauh ini..." (P5, Laki-laki, 53 tahun)

Pernyataan dari partisipan ini juga dikuatkan oleh pernyataan dari keluarga partisipan yang mengatakan bahwa :
"Ya itu tadi mas, jadi kan memang awalnya ayah saya itu sudah lama merokok kami sering mengingatkan untuk berhenti tapi ayah saya bilang dia enggak apa-apa sampai sejauh ini jadi kami hanya mampu mengontol kondisinya saja mas... (T3, Perempuan, 30 tahun).

"bigini mas, dulu suami saya pernah berhenti merokok,sekarang merokok kemabali saya Tanya katanya sekarang enggak ada gejala-apa...." (T5, Perempuan, 51 tahun).

\section{Tema 2 : Tidak Dapat Menahan Keinginan Untuk Merokok}

Tema ini mendeskripsikan tentang apa-apa saja yang menjadi alasan dari partisipan tidak dapat menahan keinginannya untuk merokok Berdasarkan hasil wawancara mendalam dengan partisipan Pasien Mengatakan Tidak Mampu Untuk Menahan Keinginan Untuk Merokok. Hal ini dapat dilihat pada hasil wawawancara berikut.

"saya ya mas kadang-kadang kalau lagi nyetir mobil dijalan rasa enggak bisa nahan kalau tidak ngerokok, yah saya buka aja kaca mobil atau stop duduk dulu,tapi keinginan saya itu kayak candu mas kalau enggak ngerokok itu tidak enak mas, saya paling tidak tahan kalau lagi nyetir mobil mas..." (P3, Laki-laki, 47 tahun).

\section{Tema 3 : Keluarga Membiarkan}

Tema ini mendeskripsikan tentang apa-apa saja yang menjadi alasan keluarga membiarkan kondisi pasien. Berdasarkan hasil 
wawancara mendalam dengan partisipan dan keluarga partisipan, didapatkan hasil bahwa keluarga bosan mengingatkan dan akhirnya membiarkan pasien. Pasien juga mengatakan saat ini, keluarganya sudah tidak peduli lagi, karena pasien tetap ingin merokok. Hal ini dapat dilihat pada hasil wawawancara berikut.

"Dulu, anak saya sering sekali
mengingatkan saya untuk berhenti
merokok, tapi karena saya tidak mau
mendengarkan omongannya, sekarang
istri saya tidak bilang apa-apa lagi saat
saya mengeluh batuk" (P3, Laki-laki, 47
tahun, Hipertensi).
"Iya, saya ini sudah sering sekali
dibilangin sama istri saya tapi karena
saya tetap merokok, akhirnya istri saya
tidak lagi peduli dengan kondisi saya."
(P4, Laki-laki, 50 tahun, Hipertensi).

Pernyataan dari partisipan ini juga dikuatkan oleh pernyataan dari keluarga partisipan yang mengatakan bahwa keluarga bosan mengingatkan dan akhirnya membiarkan pasien. Keluarga juga mengatakan Pasien juga mengatakan saat ini, mereka sudah tidak peduli lagi, karena pasien tetap ingin merokok. Hal ini dapat dilihat pada hasil wawawancara berikut.

“iya pak, saya ini sudah sering sekali
mengingatkan ayah saya ini, ya tapi mau
bagaimana lagi saya cuma manusia biasa,
saya capek, jadi sekarang ya terserah
ayah saya mau bagaimana. " (T3,
Perempuan, 30 Tahun).
"Iya, saya ini rasanya sudah ratusan kali
mengomeli suami saya, rasanya apa yang
saya omongin tidak pernah didengar, jadi
saya biarkan saja maunya suami saya
seperti apa." (P4, Laki-laki, 50 tahun,).

\section{Tema 4 : Ingin Berhenti Merokok}

Tema ini mendeskripsikan tentang apa-apa saja yang menjadi alasan dan motivasi dari partisipan ingin berhenti merokok. Berdasarkan hasil wawancara mendalam dengan partisipan dan keluarga partisipan, didapatkan hasil bahwa seluruh partisipan ingin berhenti merokok agar lebih sehat. Partisipan juga mengatakan bahwa setelah mereka mencoba berhennti merokok, badannya menjadi lebih sehat. Hal ini dapat dilihat pada hasil wawawancara berikut.

"Enggak, awalnya saya itu lupa beli rokok, dan kebetulan jarak dari rumah ke warung itu agak jauh, jadi saya malas untuk kesana, terpaksa saya tidak merokok saat itu, pada saat saya tidak merokok pernapasan saya lebih enak, jadi sejak saat itu saya ingin berhenti merokok,..." (P5, Laki-laki, 53 tahun)

"Setiap hari saya sudah membiasakan untuk tidak merokok, dan saya berharap apa yang saya lakukan ini bisa membuat kondisi tubuh saya jadi lebih baik dari sebelumnya." (P1, Laki-laki, 62 tahun)

"Iya tiap kali melihat teman yang tidak pernah merokok, saya merasa iri karena mereka tidak pernah mengeluh sesak napas seperti saya ini, jadi saya berkeinginan untuk lepas dari rokok dan menerapkan pola hidup sehat" (P3, Lakilaki, 47 tahun).

Pernyataan dari partisipan ini juga dikuatkan oleh pernyataan dari keluarga partisipan yang mengatakan bahwa keluarga juga ingin pasien berhenti merokok agar lebih sehat. Keluarga pasien juga mengatakan bahwa setelah pasien mencoba berhenti merokok, badannya menjadi lebih sehat. Hal ini dapat dilihat pada hasil wawawancara berikut.

"Iya pak, saya juga perhatikan suami saya ini, saat dia melakukan aktivitas suami saya ini tidak terlihat telihat ngos-ngosan pada saat dia tidak merokok. Jadi saya ingin sekali suami saya ini berhenti merokok sepenuhnya" (T5, Perempuan, 45 tahun)

"Saya juga sering memperhatikan suami saya, sekarang suami saya sudah membiasakan diri untuk tidak merokok, saya senang sekali melihat perubahan yang dilakukan oleh suami saya dan saya berharap suami saya ini dapat lebih sehat." (P1, Laki-laki, 62 tahun, Hipertensi)

"Iya pak, ayah saya ini sudah menyadari mana perilaku hidup sehat, terlihat dari kebiasaan ayah saya saat ini yang sudah mulai menerapkan pola hidup sehat." (T3, Laki-laki, 30 tahun. 


\section{PEMBAHASAN}

Berdasarkan pada hasil penelitian diatas, terdapat beberapa tema dalam penelitian ini, yaitu: 1) Merasa sudah sehat, 2) Tidak dapat menahan keinginan untuk merokok, 3) Keluarga membiarkan, dan 4) Ingin berhenti merokok.

\section{Tema 1 : Merasa Sudah Sehat}

Pasien didiagnosa hipertensi sudah lebih dari satu tahun dan pada saat didiagnosa pasien berhenti merokok, namun setelah pasien merasa sehat dan tidak mengalami gejala apa-apa lagi pasien mulai merokok kembali. Hal ini dilakukan pasien karena pasien memiliki keyakinan yang salah terhadap keadaan dirinya, pasien merasa apabila tubuhnya tidak mengalami gejala hipertensi seperti selalu pusing, mata berkunang-kunang, berat pada tungkuk, pasien merasa dirinya sudah sehat seperti sedia kala. Hal ini juga yang melatarbelakangi pasien kembali mengkonsumsi rokok.

\section{Berdasarkan teori Health Belive Model} (HBM), tindakan seseorang dalam mengambil keuputusan akan perilaku dalam menjaga kesehatan akan sangat dipengaruhi oleh kepercayaan orang tersebut dalam memahami situasi yang terjadi pada tubuhnya, sehingga apabila pasien merasa dirinya sudah sehat, hal ini akan mendorong pasien mengambil tindakan atau perilaku yang kembali menyimpang karena pasien merasa percaya bahwa tubuhnya sedang dalal keadaan baikbaik saja.

Kendala yang dihadapi selama proses farmakologi dan kepatuhan minum obat informan mengungkapkan banyak pasien yang tidak mengkonsumsi obat secara teratur dan beberapa pasien tidak menghabiskan obat karena merasa sudah sembuh. Hal ini sejalan dengan penelitian Dina (2017) bahwa suatu kejadian yang tidak diharapkan yang mengganggu terapi pengobatan hipertensi meliputi membutuhkan tambahan terapi obat, dosis kurang dan ketidaktaatan pasien meminum obat karena sudah merasa sehat. Kendala lain yang dihadapi yaitu pasien tidak melakukan kontrol kembali ketika obat sudah habis sehingga pemantauan terhenti dan petugas tidak dapat melihat perkembangan pasien.

\section{Tema 2 : Tidak Dapat Menahan Keinginan Untuk Merokok}

Kebiasaan merokok dianggap dapat memberikan kenikmatan bagi perokok, namun di lain pihak dapat menimbulkan dampak buruk bagi perokok sendiri maupun orangorang disekitarnya. Hal ini sebenarnya telah diketahui oleh masyarakat, bahwa merokok itu mengganggu kesehatan (Setiyanto, 2013). Perilaku merokok masih merupakan masalah kesehatan dunia karena dapat menyebabkan berbagai penyakit dan bahkan kematian (Lizam, 2009). Merokok bagi partisipan membawa dampak yang cukup besar bagi kehidupan mereka. Partisi[an merokok dalam jangka waktu lama tentu karena memperoleh efek positif antara lain membantu ketika beban pikiran semakin banyak, kepercayaan diri yang semakin bertambah, memperoleh banyak teman, hingga merasa ikut tren pada saat itu.

Nagaar et al, (2011) dalam penelitiannya menjelaskan bahwa, seseorang yang memiliki kontrol diri yang baik cenderung memiliki perilaku yang baik dan dapat menahan diri dari perbuatan yang dapat memberikan efek negatif di kemudian hari.

Penjelasan tersebut sesuai dengan hasil jawaban responden yang mengatakan bahwa responden terbanyak merasakan ada kontrol diri didalam diri mereka sebanyak 88,9\% diikuti $92,6 \%$ mengenai keinginan responden untuk menujukkan pada dirinya sendiri bahwa responden mampu dan bisa untuk berhenti merokok yang membuktikan bahwa kontrol diri cenderung dapat membuat responden menahan keinginan merokok sebagai pembuktian diri. Selain itu, penjelasan mengenai kontrol diri dapat dijadikan tameng terbukti dengan jawaban responden yang 
menunjukkan bahwa $87 \%$ responden menjawab benar pada pernyataan nomor 8 tentang perasaan responden jika responden mampu untuk berhenti merokok yang menunjukkan bahwa kontrol diri memicu adanya keinginan untuk berhenti merokok.

\section{Tema 3 : Keluarga Membiarkan}

Keluarga memiliki pengaruh yang penting sekali terhadap pembentukan identitas seorang individu dan perasaan harga diri. Keluarga memainkan suatu peran yang bersifat mendukung selama masa penyembuhan dan pemulihan pasien. Apabila dukungan semacam ini tidak ada, maka keberhasilan penyembuhan/ pemulihan (rehabilitasi) sangat berkurang (Muhlisin, 2012). Apabila dalam suatu keluarga terdapat salah satu anggota keluarga yang sakit dan keluarga membiarkan maka akan berakibat bagi kesehatannya. Sehingga dukungan keluarga berperan sangat penting untuk menjaga dan mengontrol kesehatan dan diharapkan bisa kembali normal (Kiki dkk, 2020). Salah satu penyakit yang diderita oleh partisipan yakni hipertensi. Pasien hipertensi yang tidak mendapat dukungan keluarga dapat menjadikan sulitnya pasien untuk selalu menjaga dalam perawatan hipertensi secara baik.

Kurangnya dukungan keluarga sejalan dengan hasil penelitian Kiki dkk (2020) yang meneliti dukungan keluarga pada penderita hipertensi di kelurahan sumur Boto Kecamatan Banyumanik Kota Semarang. Hasil penelitian juga menunjukkan bahwa keluarga yang kurang mendukung menjadikan pasien hipertensi sulit menjadikan tekanan darahnya normal. Sumber dukungan yang paling sering dan umum adalah diperoleh dari pasangan hidup, anggota keluarga, teman dekat, dan sanak saudara yang akrab dan memiliki hubungan yang harmonis (Kuntjoro, 2002).

\section{Tema 4 : Ingin Berhenti Merokok}

Banyak pecandu rokok yang berusaha untuk berhenti dari perilaku merokok baik karena kesadaraan diri atau karena anjuran orang lain. Namun usaha yang dilakukan selalu menemukan jalan buntu (kegagalan).

Adapun yang membuat seseorang sulit

berhenti merokok adalah nikotin karena

bersifat adiktif, sehingga membuat seorang perokok menjadi kecanduan secara fisik dan emosional.

Alasan kesehatan biasanya menjadi hal utama dalam berhenti merokok, alasan selanjutnya adalah keluarga dan ekonomi. Praktisi kesehatan dan perokok tentunya setuju bahwa memburuknya tingkat kesehatan merupakan faktor yang paling memengaruhi tingkat motivasi untuk berhenti merokok. Namun motivasi berhenti merokok saja tidaklah cukup, harus ada tindakan nyata dalam usaha berhenti merokok (Kiki dkk, 2020).

Partisipan menyatakan bahwa usaha mereka di tahun-tahun sebelumnya tidak banyak memengaruhi kemampuannya untuk berhenti secara total seperti pernyataan Engels dan Willemsen (2004), bahwa perasaan mampu untuk berhenti merokok yang rendah berakibat pada perilaku merokok yang terus berlangsung, sehingga sekalipun ada pengalaman berhasil sebelumnya namun jika tidak dibarengi niat yang kuat, tidak akan memengaruhi untuk berhenti merokok.

Hal ini sejalan dengan penelitian Ardini dan Hendriani (2012), yang menyatakan bahwa salah-satu partisipan dalam proses berhenti merokok secara mandiri pada mantan pecandu rokok dalam usia dewasa awal melewati masa-masa tiga bulan mengurangi intensitas merokoknya sampai setengah bungkus, kemudian lima sampai tujuh bulan berikutnya berhasil mengurangi hingga tiga sampai lima batang per hari, dan butuh satu setengah tahun hingga benar-benar berhenti merokok. Oleh karena itu, upaya untuk berhenti merokok bagi partisipan hanya akan sukses jika dibarengi dengan niat dan usaha yang keras untuk mengontrol keinginan merokok dalam situasi apa saja 


\section{Keterbatasan Penelitian}

Keterbatasan pada penelitian ini yaitu tidak dilakukannya member checking. Pada penelitian ini, hasil transkrip wawancara tidak dikonfirmasikan kepada partisipan penelitian. Hal ini dikarenakan pasien merupakan pasien rawat jalan yang mempunyai waktu tidak banyak, sehingga peneliti kesulitan dalam melakukan member checking. Namun untuk mengkonfirmasi hasil wawancara, peneliti melakukan debriefing, yaitu mengkonfirmasi poin-poin penting dari hasil wawancara kepada partisipan setelah proses wawancara selesai.

\section{SIMPULAN DAN SARAN}

\section{Simpulan}

Kesimpulan dari hasil penelitian ini adalah ditemukannya 4 tema dari alasan pasien dengan penyakit hipertensi masih menjadi perokok aktif, yaitu: 1) Merasa sudah sehat, 2) Tidak dapat menahan keinginan untuk merokok, 3) Keluarga membiarkan, dan 4) Ingin berhenti merokok

\section{Saran}

Berdasarkan hasil dan kesimpulan pada penelitian ini, diharapkan kita sebagai pemberi pendidikan kesehatan kepada msyarakat dapat lebih memberikan informasiinformasi terkait bahaya merokok dan pentingnya menjaga tubuh untuk selalu menjauhi asap rokok, baik dari rokok yang dihisap sendiri ataupun dari orang lain atau sebagai perokok pasif. Selain itu, diharapkan juga agar hasil penelitian ini dapat dilanjutkan dalam bentuk pengabdian kepada masyarakat dengan memberikan pendidikan kesehatan serta demonstrasi dan pelatihan kepada masyarakat guna meningkatkan kemampuan dan kapasistas masyarkat agar dapat tau dan akhirnya mau berhenti merokok secara konsisten.

\section{DAFTAR PUSTAKA}

Ardini,R.F \& Hendriani,W. (2012). Proses Berhenti Merokok secara Mandiri pada Mantan Pecandu Rokok dalam Usia Dewasa Awal.Jurnal Psikologi Pendidikan dan Perkembangan, 1 (2), $1-7$

Arikunto, S. (2006). Prosedur Penelitian Suatu Pendekatan Praktik. Jakarta: Rineka Cipta

Aula, Lisa Ellizabet. (2010). Stop Merokok. Jogjakarta: Garailmu

Benjamin EJ, Blaha MJ, Chiuve SE, Cushman M, Das SR, Deo R, et al. Heart disease and stroke statistics - 2017 update: a report from the American Heart Association. Circulation.2017

Burke, E. (2013). The Health Belief Model. Retrieved May 17, 2016 from http://www.iccwa.org.au/useruploads/f iles/soyf/2013_resources_videos/the $h$ ealth belief model.pdfevan burke.pdf

Buss, J. S., \& Labus, D. (2013). Buku saku patofisiologi menjadi sangat mudah edisi 2.Diterjemahkan oleh Huriawati Hartanto.Jakarta: EGC

Bustan \& M. Nadjib. (2015). Manajemen Pengendalian Penyakit Tidak Menular. Jakarta: Rineka Cipta.

Candradewi, D.I. (2012). Pengaruh SMS (Short Message Service) Dan Konseling Berhenti Merokok Selama 2 Bulan Terhadap Pengetahuan Dan Perilaku Merokok Pada Siswa Di SMA Muhammadiyah 3 Yogyakarta. Skripsi UMY.Yogyakarta

Center for Disease Control and Prevention (CDC) 2012. Body Mass Index: Considerations for Practitioners. 1-4

Center for Disease Control. (2014). Community Report on Autism from the Autism and Developmental Disabilities Monitoring Network.

Creswell, J.W. (2013). Penelitian Kualitatif \& desain riset : memilih di antara lima pendekatan edisi ke-3. Alihnbahasa: 
Lazuardi, A.L. 2015. Jakarta: Pustaka pelajar

Croyle, RT. (2005). Theory at a Glance: Application to Health Promotion and Health Behavior (Second Edition). U.S. Department of Health and Human Services, National Institutes of Health

Rahmantika Dina. Indentifikasi Drug Related Problems (Drps) Kategori Ketidaktepatan Obat pada Pasien Hipertensi di Instalansi Rawat Inap Rumah Sakit PKU Muhammadiyah Surakarta. 2017.

Dinkes Prov. SumSel. Profil Kesehatan Provinsi Sumatera Selatan 2010. Pusat data dan Informasi Kesehatan : Palembang. 2010

Dinkes Kota Palembang. Profil Kesehatan Kota Palembang 2017.Pusat data dan Informasi Kesehatan : Palembang. 2017

Engels R.C.M.E. dan Willemsen M. 2004. Communication about Smoking In Dutch Families: Associations Between Anti-Smoking Socialization and Adolesecent Smoking-Related Cognitions. Health Education Research, 19, 227 - 238.

Fidrianny I, Soemardji AA, Supradja I. Analisis nikotin dalam asap dan filter rokok. Jurnal Fakultas Matematika dan Ilmu Pengetahuan Alam. 2004;29:1004. 5

GATS. 2011. Global Adults Tobacco Survey Indonesia Report 2011.New Delhi : WHO Regional Office For South-East Asia

Hayden, J. A. (2014). Introduction to Health Behavior Theory, Second Edition. Wall Street Burlington: Jones and Bartlett Publishers.

Holloway, I. \& Wheeler, S. (2010). Qualitative research in nursing and health care ( $3^{\text {rd }}$ Edition). Oxford, England: Blackwell.

Indar Kurniawan, - (2017) Hubungan Perilaku Merokok Dengan Kejadian Hipertensi
Di Puskesmas Pajangan Bantul. PostDoctoral thesis, STIKES Jenderal Achmad Yani Yogyakarta.

JNC VII. 2003. The seventh report of the Joint National Committee on prevention, detection, evaluation, and treatment ofhigh blood pressure. Hypertension, 42: 1206-52.

Kementerian Kesehatan Republik Indonedia (Depkes RI) 2016. Profil Keseheatan Indonesia Tahun 2016. Kementerian Kesehatan Republik Indonesia.

Khoirudin, (2006). perbedaan kapasitas vital paru dan tekanan darah antara perokok aktif dengan perokok pasif pada siswa Madrasah Hidayatul Mubtadi'in Semarang Tahun Ajaran 2005/2006. Fakultas Ilmu Keolahragaan Universitas Negeri Semarang.

Kiki, M. N. H., Muhammad, Z., \& Fahrany, F. (2020). Dukungan Keluarga Dengan Pola Diet Pada Pasien Hipertensi : A Literature Review. Nursing Sciences Journal, 4(2), 1-7.

Kuntjoro Z, 2002. Dukungan Sosial Pada Lansia.http://www.e-psikologi.co.id

Lizam, C.T. (2009). Meningkatkan sikap positif terhadap perilaku tidak merokok dan kecenderungan untuk berhenti merokok melalui pelatihan kecerdasan emosional pada mahasiswa SMA di Kabupaten Aceh Barat Daya Nanggroe Aceh Darussalam. Tesis. Universitas Gadjah Mada, Yogyakarta.

Leventhal, H and Clearly P.D. (2010). The Smoking Problem: A Review of the Research and Theory In Behavioural Risk Modification. Psychological Bulletin. July 2010, vol. 100, No. 7.

Muhibah, F.A.B.2011.Tingkat Pengetahuan Pelajar Sekolah Menengah Sains Hulu Selangor Mengenaik Efek Rokok Terhadap Kesehatan.(KTI). Universitas Sumatera Utara. Medan.

Mu'tadin, Z. 2002. Pengantar Pendidikan dan Ilmu Perilaku Kesehatan. Yogyakarta. Andi Offset 
Muhlisin Abi. 2012. Keperawatan Keluarga. Yogyakarta: Gosyen Publishing

Moloeng \& Lexy J. (2004). Metodologi Penelitian Kualitatif Edisi Revisi. Bandung: Remaja Rosdakarya

Notoatmodjo, S.2014. Ilmu Perilaku Kesehatan. Jakarta: Rineka Cipta

Nurarif .A.H. dan Kusuma. H. (2015). Aplikasi Asuhan Keperawatan Berdasarkan Diagnosa Medis \& Nanda NIC-NOC. Jogjakarta: MediAction

Octafrida M,D.2011.Hubungan Merokok dengan Katarak di Poliklinik Mata Rumah Sakit Umum Pusat Haji Adam Malik Medan.(KTI).Universitas Sumatera Utara. Medan

Riskesdas. Badan Penelitian Pengembangan Kesehatan Kementerian Kesehatan RI 2008. Riset Kesehatan Dasar. Jakarta: Riskesdas: 2008

Riskesdas. Badan Penelitian Pengembangan Kesehatan Kementerian Kesehatan RI 2013. Riset Kesehatan Dasar. Jakarta: Riskesdas: 2013

Riskesdas. Badan Penelitian Pengembangan Kesehatan Kementerian KesehatanRI 2018. Riset Kesehatan Dasar. Jakarta: Riskesdas: 2018

Setiadi. (2013). Konsep dan praktek penulisan riset keperawatan (Ed.2)Yogyakarta: Graha Ilmu

Sirkesnas. 2016. Survei Indikator Kesehatan Nasional.Jakarta: Badan Penelitian Pengembangan Ksehatan Kementrian Kesehatan RI. 2016.

Sitepoe, M. (2000).Kekhususan Rokok Indonesia. Jakarta : PT Grasindo.

Sriani, K.I., Fakhriadi, R., \& Rosadi, D. (2017). Hubungan Antara Perilaku
Merokok Dan Kebiasaan Olahraga Dengan Kejadian Hipertensi Pada Laki-Laki Usia 18-44 Tahun,

Sudarmoko. (2015). Tetap Tersenyum Melawan Hipertensi. Yogyakarta: Atma Madia Press.

Rifa'i, Setiyanto. 2013. Faktor-Faktor Penyebab Merokok. Bandung: Alfa Beta.

Sugiyono, 2009, Metode Penelitian Kuantitatif, Kualitatifdan R\&D, Bandung : Alfabeta

Sugiyono, 2013, Metodelogi Penelitian Kuantitatif, Kualitatif Dan R\&D. (Bandung: ALFABETA)

Sukmana T. (2008). Agar Terhindar Dari

Rokok. Jakarta: Be Champion, Pp: 414.

Syafiie,R.2009.Stop Smoking. Studi Kualitatif Terhadap Pengalaman Mantan Pecandu Rokok dalam Menghentikan Kebiasaannya.(Thesis). Universitas Diponegoro. Semarang

Triyanto, Endang. 2014. Pelayanan Keperawatan Bagi Penderita Hipertensi Secara Terpadu. Yogyakarta: Graha Ilmu.

WHO. 2013. About Cardiovascular diseases. World Health Organization.Geneva. Cited July 15 th 2014.

Wismanto, Y Bagusdan Y Budi Sarwo. 2007. Strategi Penghentian Perilaku Merokok. Semarang : Unika Soegijapranata.

World Health Organization. A global brief on hypertension: silent killer, global public health crisis. 2015. 